\title{
Isolation and identification of a bovine viral diarrhea virus from sika deer in china
}

\author{
Yugang Gao ${ }^{1}$, Shijie Wang ${ }^{1}$, Rui Du', Quankai Wang ${ }^{1}$, Changjiang Sun ${ }^{2}$, Nan Wang ${ }^{3}$, Pengju Zhang ${ }^{4 *}$, \\ Lianxue Zhang ${ }^{1 *}$
}

\begin{abstract}
Background: Bovine viral diarrhea virus (BVDV) infections continue to cause significantly losses in the deer population. Better isolation and identification of BVDV from sika deer may contribute significantly to the development of prophylactic therapeutic, and diagnostic reagents as well as help in prevention and control of BVDV. However, isolation and identification of BVDV from sika deer is seldom reported in literature. In this study, we collected some samples according to clinical sign of BVDV to isolation and identification of BVDV from sika deer.

Results: we isolated a suspected BVDV strain from livers of an aborted fetus from sika deer in Changchun (China) using MDBK cell lines, named as CCSYD strain, and identified it by cytopathic effect (CPE), indirect

immunoperoxidase test (IPX) and electron microscopy $(E M)$. The results indicated that this virus was BVDV by a series of identification. The structural proteins EO gene was cloned and sequenced. The obtained EO gene sequence has been submitted to GenBank with the accession number: FJ555203. Alignment with other 9 strains of BVDV, 7 strains of classical swine fever virus (CSFV) and 3 strains of border disease virus(BDV) in the world, showed that the homology were $98.6 \%-84.8 \%, 76.0 \%-74.7 \%, 76.6 \%-77.0 \%$ for nucleotide sequence, respectively. The phylogenetic analysis indicated that new isolation and identification CCSYD strain belonged to BVDV1b.

Conclusion: To the best of our knowledge, this is the first report that BVDV was isolated and identified in sika deer. This current research contributes development new BVDV vaccine to prevent and control of BVD in sika deer.
\end{abstract}

\section{Background}

Bovine viral diarrhea virus, a single-stranded RNA is found in cattle and other ruminants worldwide [1-4]. The presence of BVDV in other domestic species such as sheep or wild species such as whitetail deer might be relevant to the epidemiology other disease in cattle [5]. The BVDV infections range from clinically in apparent infections to severe disease involving one or more organ systems. Historically, BVDV was associated with digestive tract disease including high mortality. Currently, BVDV is associated more frequently with respiratory disease and fetal infections [2]. Raise skia deer already had hundreds years at present artificially in china and farmed populations had reached hundreds of thousands

\footnotetext{
* Correspondence: pengju213@126.com; zlxbooksea@163.com

${ }^{1}$ College of Traditional Material Medicine, Jinlin Agriculture University, Changchun, 130118, PR China

${ }^{4}$ School of Life Science, Sichuan University, Chengdu, 610064, PR China Full list of author information is available at the end of the article
}

in recent year. However, bovine viral diarrhea (BVD) caused significantly losses in the deer population. It was reported that infections rates of BVDV for young deer reached $60 \% \sim 86.7 \%$ in some areas of china in recently years [6], which caused economic losses to sika deer industry due to the high morbidity and fetal infections associated with the disease. Thus, the isolation and identification of BVDV from sika deer, which is fundamental to prevent and control of BVDV in sika deer, becomes an urgent task to many researchers.

The Bovine viral diarrhea virus (BVDV) belongs to the genus pestivirus within the family Flaviviridae. BVDV is closely related to the classical swine fever virus (CSFV) and the ovine border disease virus (BDV) [7]. The pestiviral genome consists of a single stranded positive sense RNA with a length of about $12.3 \mathrm{~kb}$. It contains one larger open reading frame (ORF), which is flanked by nontranslated regions (NTR) on both genome termini. The single ORF is translated into one polyprotein, which is
C Biomed Central

() 2011 Gao et al; licensee BioMed Central Ltd. This is an Open Access article distributed under the terms of the Creative Commons Attribution License (http://creativecommons.org/licenses/by/2.0), which permits unrestricted use, distribution, and reproduction in any medium, provided the original work is properly cited. 
co-and post- translationally processed into the mature proteins $\mathrm{N}^{\text {pro }}, \mathrm{C}, \mathrm{E} 0$ (gp48, also named $\mathrm{E}^{\mathrm{rns}}$ ), E1, E2, NS2/3, NS4a, NS4b, NS5a and NS5b by viral and cellular proteases [8-10]. E0 protein, the main structural protein of BVDV, plays a very important role in inducing protective immunoreaction against BVDV and diagnosing virus [2].

Although BVDV from the skia deer has been seriously concerned, there are only a few articles with respect to the prevalence of BVDV investigations and BVDV clinical sign [6], Particular, lacking in articles with regard to the molecular virology, gene sequences and genetically engineering vaccine of local BVDV isolates in China due to BVDV from skia deer without isolation and identification. The purpose of our study was isolation and identification BVDV from skia deer by a series of methods, which contributes this disease control.

\section{Results}

\section{Isolation and identification}

The significant cytopathic effects (CPE) were observed in MDBK cell infected with virus $24 \mathrm{~h}-48 \mathrm{~h}$. The MDBK cells generate obvious cell lesion and net between cells in comparison to the control cells, which is consistent with CPE of BVDV on MDBK cell (Figure 1). The IPX assay showed that the well of positive serum appeared red-brown cytoplasmic staining, which suggested that new isolation virus might be BVDV. The negatively stained virus particles extracted from liver were approximately $40 \mathrm{~nm}-60 \mathrm{~nm}$ in diameter when examined by electron microscope (Figure 2), and displayed a typical BVDV morphology.

\section{Amplification, sequencing and analysis of EO gene}

The MDBK cell infected with CCSYD were positive by the RT-PCR assays, and the expected sizes of the PCR products, $706 \mathrm{bp}$ for E0 of CCSYD, were observed as clear electrophoretic band (Figure 3). The obtained E0 genes segment by sequencing has been deposited in GeneBank under accession No. FJ55520. Alignment with other 9 strains of BVDV, 7 strains of CSFV and 3 strains of $\mathrm{BDV}$ in the world, showed that the homology were
98.6\%-84.8\%, 76.0\%-74.7\%, 76.6\%-77.0\% for nucleotide sequence, respectively (Table 1 ), which shows that there is no significant deviation of CCSYD E0 with conventional BVDV.

\section{Phylogenetic analysis}

To better understand the relationship of CCSYD to other 9 strain of BVDV, 7 strains of CSFV and 3 strains of BDV variants co-circulating in the word, genetic sequences of Pestivirus from cattle, swine and ovine in GenBank were used to construct phylogenetic trees. Figure 4 clearly showed that E0 genes of the CCSYD belonged to BVDV1b.

\section{Discussion}

In the present study, CCSYD strain was isolated from skia deer in Changchun city. By employing a series of biochemical and biophysical methods, we have firstly identified that CCSYD might be BVDV. The BVDV can be classified into biotypes and genotypes [2]. Biotypes are based on the presence or absence of visible $\mathrm{CPE}$ in infected cell cultures, cytopathic (CP) or noncytopathic (NCP) [2]. Genotype classification is based on divergence in the viral genome sequences revealed by phylogenetic analysis [11-15]. Based on phylogenetic comparison, the virus can be classified into two genotypes: BVDV1 and BVDV2. Whereas BVDV1 has a world-wide distribution, BVDV2 appears to be highly prevalent only in North America $[13,16]$ and relatively rare in other continents $[15,17]$. Moreover, recently the BVDV1 and BVDV2 genotypes have been further divided into subgenotypes BVDV1a, BVDV1b, BVDV2a, and BVDV2b in North American $[18,19]$. Genetic and phylogenetic analysis showed that the virus belonged to BVDV1b. Similar strains contain the VEDEVAC strain isolated Hungary, with 98.7\% homology for amino acid. Moreover, we have also successfully cloned NS2/3 genes of CCSYD strain, with 100\% homology for amino acid and NS2/3 genes of VEDEVAC strain, which further showed that CCSYD strain and VEDEVAC strain belonged to BVDV1b.

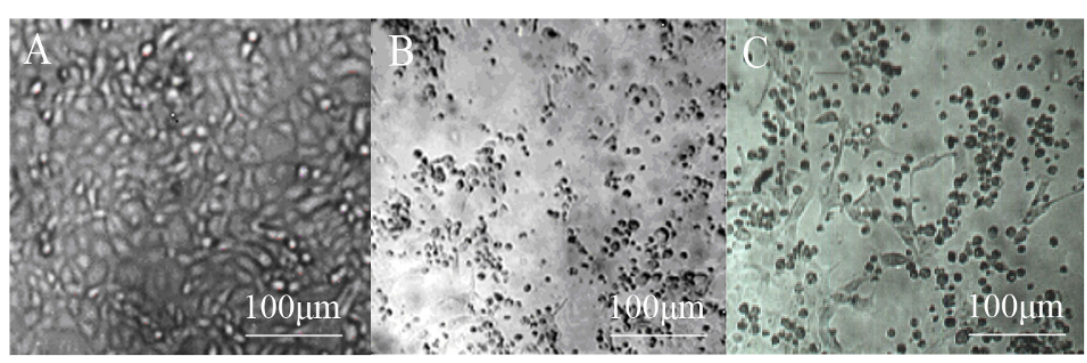

Figure 1 The CPE of BVDV. A: The MDBK cell as negative control; B: The CPE of $C_{24} V$ strain as positive control. C: The CPE of CCSYD strain. 


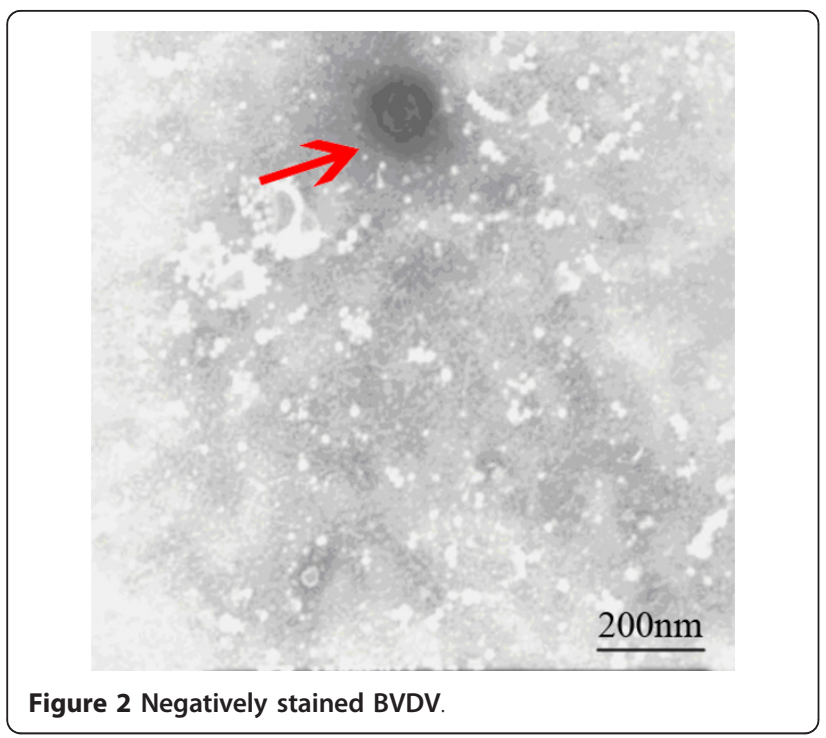

The protection conferred by conventional inactivated BVDV vaccines is strongly correlated with genetically and antigenically of specific BVDV strain. In addition to, an increasing frequency of skia deer with elevated antibody titers to BVDV suggests that exposure to field strains has not been diminished despite the use of both management and vaccine [6]. This suggests that current vaccine may be inadequate in conferring skia deer protection against the acute disease in skia deer. Design of efficacious vaccines must be based on specific BVDV strain about the immune responses critical to development of protection. Hence, it is appropriate to guide the selection of the vaccine strain according to the specific BVDV strain from local area and similar strain, which depend on further studies of BVDV from skia deer distribution and identification. There is currently no commercial skia deer BVDV vaccine used in China, and

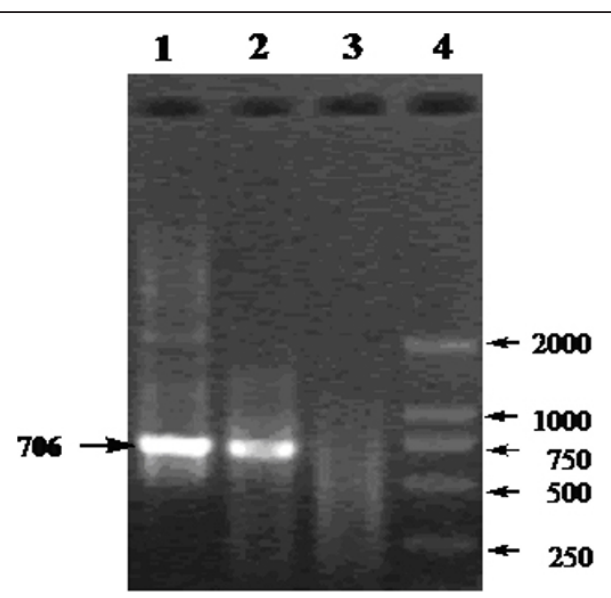

Figure 3 The amplified products by RT-PCR. Lan1 and Lan2: E0 gene from infected MDBK cell; Lan3: MDBK cell as negative control. therefore, it is important to select the vaccine candidate strain from control BVD from skia deer. Inactivated CCSYD strain by a certain method might be employed in preventing and counterchecking the skia deer BVD in Jilin province. Moreover, selected $\mathrm{E}_{0}$ protein of CCSYD construction a DNA vaccine might induce cellular immune response and antibody responses specific for BVD from skia deer. Therefore, isolation and identifcation of a skia deer bovine viral diarrhea virus (CCSYD) contributes development new BVDV vaccine to prevent and control of BVDV in sika deer.

\section{Conclusions}

The present study described the isolation and identifcation of a skia deer bovine viral diarrhea virus (CCSYD) isolated from sick skia deer for the first time in China. This study provided a detailed analysis of the genetic and evolution of CCSYD which is likely to be helpful to guide efficient diagnostic, preventive and control strategies against BVD from skia deer in China.

\section{Materials and methods}

\section{Virus isolation}

Field samples came from skia deer at field of Changchun (China), which might infected with BVDV according to clinical sign such as diarrhea and miscarriage and stillbirth. Skia deer liver was collected from an aborted fetus deer. A total of $1 \mathrm{~g}$ of fresh liver tissue was homogenized in $4 \mathrm{ml}$ of phosphate-buffered saline (PBS, PH 7.2) and then repeated freeze thawed 3 times, and centrifuged at $5000 \mathrm{rpm}$ for $30 \mathrm{~min}$. A certain liver extract was then inoculated onto MDBK monolayer cultures, $25 \mathrm{~cm}$ flasks with a $1 \mathrm{ml}$ inoculum (1:10 dilution of original samples) and the total volume was $5 \mathrm{ml}$. The MDBK cultures were observed for 6 days with presence or absences of CPE recorded. The cultures were frozen at $70^{\circ} \mathrm{C}$, thawed and supernatants collected after centrifugation with subsequent storage at $70^{\circ} \mathrm{C}$. Uninoculated cultures were included as negative controls and inoculated $\mathrm{C}_{24} \mathrm{~V}$ as positive control.

\section{Identification of virus}

BVDV was detected by indirect immunoperoxidase test (IPX) and electron microscopy technique (EM). For IPX, the test was carried out on 96-well plates using lowpassage MDBK cells. Serum $(20 \mu \mathrm{l})$ was added to each of four wells before the addition of $100 \mu \mathrm{l}$ of cell suspension. Positive and negative control sera were run on each plate. The test plates were incubated for 4 days in $5 \% \mathrm{CO}_{2}, 37^{\circ} \mathrm{C}$. Plates were fixed and dried, then stained with immunoperoxidase as described by Meyling [20], using a polyclonal bovine anti-BVDV serum (BVD virus positive control serum, China) to detect the virus. The presence of red-brown cytoplasmic staining in any of 
Table 1 Homology of EO gene sequence of different RHDV isolates

\begin{tabular}{|c|c|c|c|c|c|c|c|c|c|c|c|c|c|c|c|c|c|c|c|c|}
\hline & $\mathrm{C}_{24} \mathrm{~V}$ & R1935 & naqdl & SD-1 & Bega & Y546 & CCSYD & VEDEVAC & ILLC & OSLOSS & ALD & GPE & Brescia & SM & $\mathrm{C}$ & LN9912 & $\mathrm{JL}$ & BD31 & BDVX818 & C413 \\
\hline $\mathrm{C}_{24} \mathrm{~V}$ & & 99.5 & 91.5 & 92.7 & 88.4 & 88.6 & 84.9 & 84.6 & 85.6 & 85.2 & 75.5 & 75.4 & 74.5 & 75.5 & 76.0 & 75.8 & 75.2 & 77.1 & 77.0 & 76.6 \\
\hline R1935 & 0.6 & & 91.5 & 92.7 & 88.6 & 88.9 & 85.2 & 84.8 & 85.8 & 85.2 & 75.5 & 75.4 & 74.6 & 75.5 & 76.0 & 75.8 & 75.3 & 77.1 & 77.0 & 76.5 \\
\hline naqdl & 11.8 & 11.8 & & 91.5 & 87.7 & 87.8 & 86.2 & 85.5 & 87.0 & 85.6 & 75.6 & 75.8 & 75.2 & 75.3 & 75.1 & 74.8 & 75.1 & 77.8 & 77.5 & 76.9 \\
\hline SD-1 & 10.0 & 10.0 & 11.8 & & 88.1 & 88.6 & 84.8 & 84.7 & 85.7 & 85.7 & 75.1 & 74.9 & 74.0 & 74.9 & 75.4 & 75.2 & 74.7 & 78.9 & 78.0 & 76.7 \\
\hline Bega & 16.9 & 16.5 & 18.0 & 17.4 & & 95.1 & 85.8 & 85.8 & 87.4 & 86.4 & 74.8 & 74.9 & 74.9 & 74.9 & 74.5 & 74.5 & 76.3 & 77.7 & 77.6 & 76.9 \\
\hline Y546 & 16.6 & 16.2 & 17.9 & 16.5 & 6.5 & & 85.5 & 85.4 & 86.7 & 86.5 & 74.5 & 74.6 & 74.7 & 74.4 & 73.9 & 73.9 & 76.2 & 79.1 & 78.2 & 76.3 \\
\hline CCSYD & 22.8 & 22.4 & 20.5 & 23.2 & 21.2 & 21.8 & & 98.6 & 92.7 & 95.1 & 76.0 & 76.1 & 75.1 & 75.8 & 74.7 & 74.9 & 75.5 & 76.6 & 76.7 & 77.0 \\
\hline VEDEVAC & 23.5 & 23.1 & 21.8 & 23.4 & 21.2 & 22.1 & 1.8 & & 93.4 & 95.8 & 76.2 & 76.3 & 75.1 & 76.0 & 74.9 & 74.9 & 75.8 & 76.9 & 76.7 & 77.4 \\
\hline ILLC & 21.7 & 21.3 & 19.2 & 21.5 & 18.6 & 19.9 & 10.0 & 9.0 & & 92.6 & 76.0 & 76.2 & 75.3 & 76.0 & 75.5 & 75.5 & 76.7 & 77.4 & 77.1 & 77.8 \\
\hline OSLOSS & 22.6 & 22.6 & 21.6 & 21.5 & 20.2 & 20.0 & 6.5 & 5.5 & 10.3 & & 76.1 & 76.2 & 75.2 & 76.0 & 75.2 & 75.2 & 76.1 & 77.3 & 76.6 & 77.1 \\
\hline ALD & 40.9 & 40.9 & 40.8 & 42.3 & 42.7 & 43.6 & 40.1 & 39.4 & 39.9 & 39.6 & & 99.3 & 94.7 & 98.6 & 96.6 & 96.6 & 88.2 & 79.2 & 79.1 & 77.6 \\
\hline GPE & 41.2 & 41.2 & 40.4 & 42.6 & 42.4 & 43.2 & 39.8 & 39.1 & 39.3 & 39.3 & 0.9 & & 94.1 & 97.9 & 96.1 & 96.1 & 88.5 & 79.4 & 79.4 & 77.7 \\
\hline Brescia & 43.2 & 42.9 & 41.6 & 44.6 & 42.1 & 42.6 & 42.0 & 41.9 & 41.3 & 41.5 & 7.1 & 8.0 & & 94.4 & 92.8 & 93.3 & 87.4 & 78.3 & 78.0 & 76.8 \\
\hline SM & 40.9 & 40.9 & 41.6 & 42.6 & 42.3 & 43.7 & 40.5 & 39.8 & 39.8 & 39.7 & 1.8 & 2.7 & 7.5 & & 96.4 & 96.6 & 88.3 & 79.2 & 79.1 & 77.3 \\
\hline C & 39.8 & 39.8 & 42.2 & 41.4 & 43.7 & 45.1 & 43.3 & 42.5 & 41.0 & 41.8 & 4.4 & 5.2 & 9.8 & 4.7 & & 99.5 & 86.8 & 78.9 & 78.7 & 77.8 \\
\hline LN9912 & 40.3 & 40.3 & 42.7 & 41.9 & 43.6 & 45.1 & 42.6 & 42.5 & 40.9 & 41.7 & 4.4 & 5.2 & 9.2 & 4.4 & 0.6 & & 86.8 & 78.9 & 78.7 & 77.6 \\
\hline$J L$ & 41.6 & 41.3 & 42.0 & 43.0 & 38.8 & 39.1 & 41.0 & 40.3 & 38.1 & 39.4 & 17.3 & 16.7 & 18.5 & 17.0 & 19.7 & 19.7 & & 78.5 & 79.0 & 76.7 \\
\hline BD31 & 37.2 & 37.2 & 35.8 & 33.5 & 36.0 & 33.0 & 38.3 & 37.6 & 36.6 & 36.8 & 33.7 & 33.5 & 35.6 & 33.8 & 34.5 & 34.5 & 34.8 & & 92.3 & 77.4 \\
\hline BDVX818 & 37.4 & 37.4 & 36.5 & 35.4 & 36.3 & 35.0 & 38.1 & 38.2 & 37.2 & 38.5 & 33.9 & 33.4 & 36.4 & 33.9 & 34.9 & 35.0 & 33.9 & 10.6 & & 76.7 \\
\hline C413 & 38.4 & 38.7 & 37.8 & 38.2 & 37.8 & 39.1 & 37.2 & 36.5 & 35.5 & 36.9 & 36.2 & 35.9 & 37.9 & 37.0 & 35.7 & 36.2 & 37.9 & 36.7 & 38.3 & \\
\hline
\end{tabular}




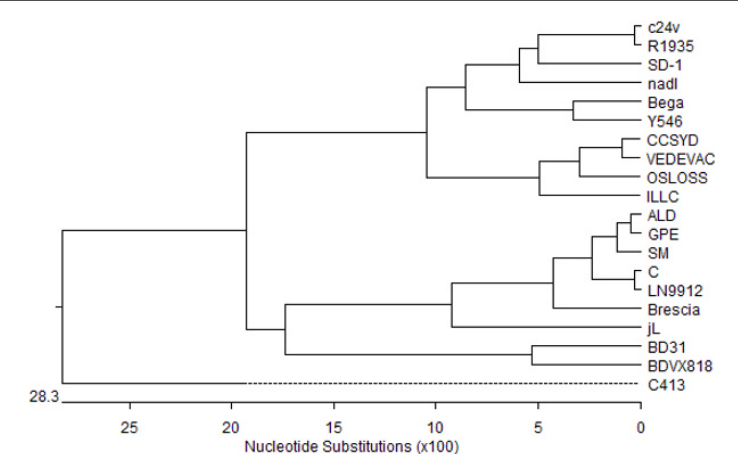

Figure 4 Phylogenetic analysis of EO protein sequence of different BVDV isolates

the wells exposed to the specific anti-BVDV antibody denoted a positive result. For electron microscopy technique (EM), chloroform (1/10 of the volume of the liver extract) was added into the liver extract, and then the liver extract) was added into the liver extract, and then the mixture was incubated for $30 \mathrm{~min}$ at $4^{\circ} \mathrm{C}$ and then centrifuged at $12000 \mathrm{rpm}$ for $30 \mathrm{~min}$. The precipitate was resuspended in $0.005 \mathrm{M}$ moderate phosphate buffered saline (PBS; PH 7.2), and negatively stained with $2 \%$ phosphotungstic acid. The specimens were examined with a transmission electron microscope (Hitachi-8100, Japan) at $80 \mathrm{kV}$.

\section{PCR amplification and sequencing}

Total RNA was isolated from infected MDBK cell using TRIzol reagent (Invitrogen China) according to the manufacturer's protocol and as described in the online supplement. In short, $200 \mu \mathrm{l}$ infected MDBK cell was incubated with $1 \mathrm{ml}$ TRIzol for $5 \mathrm{~min}$ at room temperature (RT). Cell debris was removed by centrifugation $\left(12,000 \times \mathrm{g}\right.$ at $4^{\circ} \mathrm{C}$ for $\left.10 \mathrm{~min}\right)$ and $0.4 \mathrm{ml}$ chloroform was added. After vortexing the mix was incubated for $5 \mathrm{~min}$ at RT. The phases were separated by centrifugation $\left(12,000 \times \mathrm{g}\right.$ at $4^{\circ} \mathrm{C}$ for $\left.15 \mathrm{~min}\right)$ and the aqueous phase was transferred to a new tube. $0.6 \times$ volume of isopropyl alcohol and a $0.1 \times$ volume of $3 \mathrm{M}$ sodium acetate were added to this aqueous phase and incubated for $10 \mathrm{~min}$ at $4{ }^{\circ} \mathrm{C}$. The precipitated RNA was pelleted by centrifugation $\left(12,000 \times \mathrm{g}\right.$ at $4^{\circ} \mathrm{C}$ for $\left.15 \mathrm{~min}\right)$ and after the removal of the supernatant the RNA pellet was washed twice with 70\% ethanol. After drying, the RNA was resuspended in $30 \mu \mathrm{l}$ DEPC-treated water. Using mRNA as template, single-stranded cDNAs were generated by Superscript II reverse transcriptase (Invitrogen) according to the manufacturer's directions. The E0 primer sequences were as follows: sense prime: 5'-CCGGA TCCACCATGGAAAACATAACACAGTGG-3'; antisense prime: 5'- GCCTCGAGTTAAGCGTATGCTC CAAACCACGT -3 '. The PCR conditions were $94^{\circ} \mathrm{C}$ for
3 min, followed by 30 cycles of DNA amplification (45s at $94^{\circ} \mathrm{C}, 1 \mathrm{~min}$ at $61^{\circ} \mathrm{C}$, and $1 \mathrm{~min} 30 \mathrm{~s}$ at $72^{\circ} \mathrm{C}$ ) and 8 min incubation at $72^{\circ} \mathrm{C}$. PCR products were separated by electrophoresis at a constant voltage $(2 \mathrm{~V} / \mathrm{cm})$ in a $1.2 \%(\mathrm{w} / \mathrm{v})$ agarose gel. The full-length E0 gene subjected to DNA sequencing.

\section{Analysis of sequence}

The sequence data were analyzed with computer programs such as DNAMAN and DNASTAR. Phylogenetic analysis was done by the distance-based Neighbor-joining method using software EGA 4.1. (DNAStar Inc.).

\section{Abbreviations}

BDV: Border Disease Virus; BVD: Bovine viral diarrhea; BVDV: Bovine Viral Diarrhea Virus;CPE: Cytopathic Effects; CSFV: Classical Swine Fever Virus; DNA: Deoxyribonucleic Acid; EM: Electron Microscopy; IPX: Indirect Immunoperoxidase; MDBK: Bovine Kidney; PCR: Polymerase Chain Reaction; RNA: Ribonucleic Acid.

\section{Acknowledgements}

The authors gratefully acknowledge the financial support provided by China Postdoctoral Science Foundation (20090461042), Supported by Ministry of Science and Technology of China(2009GJB10031) and Supported by National Natural Science Foundation of China (30570185).

\section{Author details}

${ }^{1}$ College of Traditional Material Medicine, Jinlin Agriculture University, Changchun, 130118, PR China. ${ }^{2}$ College of Traditional Material Medicine, Jinlin University, Changchun, 130118, PR China. ${ }^{3}$ China Institute of Veterinary Drug Control, Beijing, PR China. ${ }^{4}$ School of Life Science, Sichuan University, Chengdu, 610064, PR China.

\section{Authors' contributions}

YG and PZ participated in the design and conducted the majority of the experiments in the study and drafted the manuscript. RD and SW contributed to the interpretation of the findings and revised the manuscript. QW and NW edited the manuscript. CS performed analyses of data. All authors read and approved the final manuscript.

\section{Competing interests}

The authors declare that they have no competing interests.

Received: 17 January 2011 Accepted: 25 February 2011 Published: 25 February 2011

\section{References}

1. Baker J: Bovine viral diarrhea virus: a review. Journal of the American Veterinary Medical Association (USA) 1987, , 190: 1449-1458.

2. Baker J: The clinical manifestations of bovine viral diarrhea infection. The Veterinary Clinics of North America Food Animal Practice 1995, 11(3):425-445.

3. Reimann I, Semmler I, Beer M: Packaged replicons of bovine viral diarrhea virus are capable of inducing a protective immune response. Virology 2007, 366(2):377-386.

4. Zemke J, Knig P, Mischkale K, Reimann I, Beer M: Novel BVDV-2 mutants as new candidates for modified-live vaccines. Veterinary microbiology 2010 , 142(1-2):69-80.

5. Passler T, Walz P, Ditchkoff S, Givens M, Maxwell H, Brock K: Experimental persistent infection with bovine viral diarrhea virus in white-tailed deer. Veterinary microbiology 2007, 122(3-4):350-356.

6. Rui Du, Wei Du, Shuzhi Wang: Epidemiological investigation on BVDV infected young skia deer. Journal of Jllin Agricultural University 2000, 22(3):89-91.

7. Byers SR, Snekvik KR, Righter DJ, Evermann JF, Bradway DS: Disseminated bovine viral diarrheavirus in apersistently infected alpaca(Vicugna pacos) cria. J Vet Diagn Invest 2009, 21:145-148. 
8. Collett M, Larson R, Gold C, Strick D, Anderson D, Purchio A: Molecular cloning and nucleotide sequence of the pestivirus bovine viral diarrhea virus. Virology 1988, 165(1):191-199.

9. Lackner T, Muller A, Pankraz A, Becher P, Thiel H, Gorbalenya A, Tautz N: Temporal modulation of an autoprotease is crucial for replication and pathogenicity of an RNA virus. Journal of virology 2004, 78(19):10765-10775.

10. Mendez E, Ruggli N, Collett M, Rice C: Infectious bovine viral diarrhea virus (strain NADL) RNA from stable cDNA clones: a cellular insert determines NS3 production and viral cytopathogenicity. Journal of virology 1998, 72(6):4737-4745.

11. Becher P, Orlich M, Kosmidou A, Knig M, Baroth M, Thiel H: Genetic diversity of pestiviruses: identification of novel groups and implications for classification. Virology 1999, 262(1):64-71.

12. Couvreur $B$, Letellier C, Collard A, Quenon P, Dehan P, Hamers C, Pastoret $P$, Kerkhofs P: Genetic and antigenic variability in bovine viral diarrhea virus (BVDV) isolates from Belgium. Virus research 2002, 85(1):17-28.

13. Evermann J, Ridpath J: Clinical and epidemiologic observations of bovine viral diarrhea virus in the northwestern United States. Veterinary microbiology 2002, 89(2-3):129-139.

14. Vil ek, Paton D, Durkovic B, Strojny L, Ibata G, Moussa A, Loitsch A, Rossmanith W, Vega S, Scicluna M: Bovine viral diarrhoea virus genotype 1 can be separated into at least eleven genetic groups. Archives of virology 2001, 146(1):99-115.

15. Wolfmeyer A, Wolf G, Beer M, Strube W, Hehnen H, Schmeer N, Kaaden O: Genomic (5;ä UTR) and serological differences among German BVDV field isolates. Archives of virology 1997, 142(10):2049-2057.

16. Fulton R, Saliki J, Confer A, Burge L, d'Offay J, Helman R, Bolin S, Ridpath J, Payton M: Bovine viral diarrhea virus cytopathic and noncytopathic biotypes and type 1 and 2 genotypes in diagnostic laboratory accessions: clinical and necropsy samples from cattle. Journal of Veterinary Diagnostic Investigation 2000, 12(1):33-38.

17. Sakoda Y, Ozawa S, Damrongwatanapokin S, Sato M, Ishikawa K, Fukusho A: Genetic heterogeneity of porcine and ruminant pestiviruses mainly isolated in Japan. Veterinary microbiology 1999, 65(1):75-86.

18. Flores E, Ridpath J, Weiblen R, Vogel F, Gil L: Phylogenetic analysis of Brazilian bovine viral diarrhea virus type 2 (BVDV-2) isolates: evidence for a subgenotype within BVDV-2. Virus research 2002, 87(1):51-60.

19. Ridpath J, Neill J, Frey M, Landgraf J: Phylogenetic, antigenic and clinical characterization of type 2 BVDV from North America. Veterinary microbiology 2000, 77(1-2):145-155.

20. Meyling A: Detection of BVD virus in viremic cattle by an indirect immunoperoxidase technique. 1984, 37-46.

doi:10.1186/1743-422X-8-83

Cite this article as: Gao et al: Isolation and identification of a bovine viral diarrhea virus from sika deer in china. Virology Journal 2011 8:83.

\section{Submit your next manuscript to BioMed Central and take full advantage of:}

- Convenient online submission

- Thorough peer review

- No space constraints or color figure charges

- Immediate publication on acceptance

- Inclusion in PubMed, CAS, Scopus and Google Scholar

- Research which is freely available for redistribution 